\title{
PASSOVER AND LAST SUPPER
}

\author{
Robin Routledge
}

\begin{abstract}
Summary
The Synoptic Gospels present the Last Supper as a Passover meal. Whether this coincided with the actual Passover or, as some suggest, was held a day early, it was viewed by the participants as a Passover meal, and the words and actions of Jesus, including the institution of the Lord's Supper, would have been understood within that context. In order to better appreciate the significance of what happened at the Last Supper, this article looks at the form that the Passover celebration is likely to have taken at the time of Jesus, and notes links with the meal Jesus shared with his disciples.
\end{abstract}

\section{Introduction}

The Old Testament gives details of festivals appointed by God which are linked with historical events and which serve as a continuing reminder of God's saving power. These celebrations are rich in theological content, and also contain symbolism that points ultimately to Jesus, in whom the deeper significance of the festivals is fulfilled. In addition to their theological and symbolic significance, because the observance of these festivals was part of Jewish worship in the first century CE, knowing about them helps us to understand more about the world in which Jesus and the early Church lived and taught. For most Gentile believers, though, that is as far as the interest goes. Jesus observed the traditional Jewish holidays, ${ }^{1}$ but that was because he was born a Jew; in general Gentile believers were not expected to observe what would have been, to them, part of a foreign culture. ${ }^{2}$

The link between Jesus and the Passover presented in the New Testament, however, gives this festival a special importance for

\footnotetext{
${ }^{1}$ E.g. Passover (e.g. Lk. 2:41; 22:8; Jn. 2:23; Acts 20:6); Tabernacles (Jn. 7:1-11); Dedication (Jn. 10:22-23). The feast of the Jews in Jn. 5:1 has been variously identified as Passover, Purim, Tabernacles or Trumpets. See also Acts 2:1.

2 E.g. Acts 15:28-29.
} 
Christians. Jesus is identified with the Passover sacrifice. ${ }^{3}$ The Last Supper, including the bread and wine, which Jesus shared with his disciples and which form part of the Lord's Supper today, is traditionally thought to have been a Passover meal. The Church's observance of the Eucharist is very different from what happened at the original meal; nevertheless its symbolism can be shown to be rooted in the Passover. The purpose of this article is to look at the form of the Passover celebration during the time of Jesus, and to show how Jesus' words and actions at the Last Supper not only fit well into the context of the Passover meal, but also take on increased significance when viewed in this way.

In recent times there has been increased interest among Christians in the celebration of the Passover, and concern has been expressed over the appropriateness of Christians participating in what is, despite its link with the Last Supper, a distinctively Jewish festival. It has been noted that in Jesus' day the Passover Seder (the evening celebration which included the Passover meal) was so different from current Jewish practice that participants in the latter are more likely to be confused, than to gain any helpful insights into the Lord's Supper. ${ }^{4}$ It is worth noting, too, that from earliest times the Church has separated out the Eucharistic elements of bread and wine, which became part of a weekly celebration, from the rest of the Passover meal. The writers of the Synoptic Gospels do present the Last Supper as a Passover meal; but they emphasise only the bread and wine, and do not refer to other traditional elements such as the lamb and bitter herbs. ${ }^{5}$ Paul emphasises the theological significance of Christ as the Passover lamb, but he does not link this with his instructions about the Lord's Supper. This suggests that the Passover setting is important historically and theologically, but not liturgically. The Quartodecimans, in the second century in Asia Minor, did celebrate a Eucharist on the night of the Jewish Passover, though this was not a Passover meal but a fast, which concluded with the elements of bread and wine in the early morning. ${ }^{6}$ If the early Church did not set the

\footnotetext{
${ }^{3}$ E.g. Jn. 19:36 (cf. Ex. 12:46); 1 Cor. 5:7-8.

4 See, e.g., F.C. Senn, 'Should Christians Celebrate the Passover?' in P.F. Bradshaw, L.A. Hoffman (eds.), Passover and Easter (Two Liturgical Traditions, 6; Notre Dame, Indiana: University of Notre Dame, 1999), 183-205.

5 Mt. 26:23 may be an oblique reference to the Passover custom of dipping the bitter herbs.

6 See Senn, 'Should Christians Celebrate the Passover', 189-90; Joachim Jeremias, The Eucharistic Words of Jesus (New Testament Library; London: SCM, 1960), 122-25.
} 
celebration of the Eucharist in the context of a Passover meal we must approach the current trend towards their reunion with some caution. That, though, should not stand in the way of us seeking to gain insights into the significance of what took place at the Last Supper by looking at it in its original (Passover) setting.

\section{Was the Last Supper a Passover Meal?}

This is a thorny question that has been the subject of many studies. ${ }^{7}$ The Synoptic Gospels indicate that the meal that Jesus shared with his disciples on the night before his arrest was a Passover meal. ${ }^{8}$ It is suggested that the Fourth Gospel, wanting to emphasise the identification of Jesus with the Passover sacrifice, ${ }^{9}$ places the crucifixion a day earlier than the other Gospels - at the time the Passover lambs were being sacrificed in the Temple. ${ }^{10}$

One approach to this difficulty is to accept that the accounts cannot be reconciled, and to choose between them. ${ }^{11}$ The traditional view is that the Synoptic Gospels paint the more accurate picture historically, whilst the Fourth Gospel focuses on theological symbolism, and has adapted the chronology in order to place the death of Jesus at the time of the Temple sacrifices. More recent scholarly opinion has tended to

\footnotetext{
7 See especially, Jeremias, Eucharistic Words, 15-88; see also, e.g., D.A. Carson, 'Matthew' in F.E. Gaebelein (ed.), The Expositor's Bible Commentary 8 (Grand Rapids: Zondervan, 1984), 528-32; W.M. Christie, 'Did Christ Eat the Passover with His Disciples?, ExpT 43 (1931-32), 515-19; A. Edersheim, The Temple, its Ministries and Services (Grand Rapids: Eerdmans, 1992), 389-401; R.T. France, "Chronological Aspects of "Gospel Harmony", Vox Evangelica 16 (1986), 43-54; A.J.B. Higgins, The Lord's Supper in the New Testament (London: SCM, 1952); 'The Origins of the Eucharist', NTS 1 (1954-55), 200-209; G.D. Kilpatrick, 'The Last Supper', ExpT 64 (1952-53), 4-8; A.R.C. Leaney, 'What Was the Lord's Supper?', Theology 70 (1967), 51-62; I.H. Marshall, Last Supper and Lord's Supper (Exeter: Paternoster, 1980), 57-75; J. Stallings, Rediscovering Passover (San Jose: Resource Publications, 1995), 158-69; Leon Morris, The Gospel According to John, (New London Commentaries; London: Marshall, Morgan \& Scott, 1971), 774-86; H.L. Strack, P. Billerbeck, Komentar zum Neuen Testament aus Talmud und Midrasch 4 vols. (Munich: 1922-28), 2:812-53; N. Walker, 'Jaubert's Solution of the Holy Week Problem', ExpT 72 (1959-60), 93-94.

${ }^{8}$ Lk. 22:7-17; Mt. 6:17-19; Mk. 14:12-14; see Jeremias, Eucharistic Words, 4162; see also Higgins, The Lord's Supper, 20-23; Marshall, Last Supper, 58-62; Morris, John, 774-75.

${ }^{9}$ E.g. Jn. 19:36 (cf. Ex. 12:46).

10 Jn. 13:1-2a; 18:28; 19:14. Though there may also be Passover elements in John's account; see, e.g., Higgins, The Lord's Supper, 22; Jeremias, Eucharistic Words, 81-82.

${ }^{11}$ See, e.g., Higgins, 'Origins of the Eucharist'.
} 
favour John's chronology, and views references to the Passover in the Synoptics as later additions by the early Church, which had come to interpret the Lord's Supper as a 'Christian Passover'.

Attempts to harmonise the Gospel accounts include suggestions that the Last Supper may have been some other kind of fellowship meal, maybe eaten in anticipation of the Passover; or that Jesus and his disciples celebrated the Passover according to a variant calendar. ${ }^{12}$ If so, they may have eaten the meal early - though probably without a lamb. This seems unlikely in the light of Jesus' request for a place to eat the Passover. ${ }^{13}$ Few who support John's chronology would doubt that the similar expression in John 18:28 refers to a meal which included the Passover lamb; so why would the same not apply in the Synoptics? Of course it could be argued that if the expression refers to the Passover meal in the Synoptics, it is reasonable to suppose it also refers to the Passover meal in John. It is possible, though, that John, in the interests of theological symbolism, used the term to pascha more loosely, to refer to one of the other sacrifices offered during Passover week. ${ }^{14}$

The lack of clear evidence means that we cannot be sure about the chronology. In my view it is more likely that the Last Supper was a true Passover meal and the following outline will be based on that assumption. However, even if the Last Supper was eaten the day before Passover, the language of Synoptic Gospels indicates that Jesus and his disciples celebrated it as a Passover meal. The only difference then would have been the absence of the lamb, and since this does not figure in the symbolism of the meal, the substance of what follows still stands.

\section{The Passover Celebration}

Passover (in Hebrew, Pesach) is held on the evening of 14th Nisan, and is a celebration of Israel's deliverance from bondage in Egypt. ${ }^{15}$ The seven-day Feast of Unleavened Bread immediately follows it in

12 See, e.g., Jeremias, Eucharistic Words, 16-36; Morris, John, 779-84; France, 'Chronological Aspects', 44-47; Kilpatrick, 'The Last Supper'.

13 Mt. 26:17; Mk. 14:12, 14; Lk. 22:8, 11, 15.

14 See, e.g., Edersheim, Temple, 218, 251-52, 395-96; Stallings, Rediscovering Passover, 167-69. Here and elsewhere John appears to use deliberately ambiguous terminology which allows him to draw attention to the theological truth that Jesus is the fulfilment of the Passover sacrifice.

${ }^{15}$ Ex. 12;'Lv. 9:1-5; Dt. 16:1-8. 
the Hebrew calendar; there is debate about the historical relationship between the two festivals, however, by the early post-exilic period (and probably much earlier), they were celebrated together as a combined festival. ${ }^{16}$ This was a pilgrim feast, centred on the Jerusalem Temple; the Passover lambs were sacrificed as part of the Temple ritual, and their blood was sprinkled onto the altar, rather than painted onto doorposts. ${ }^{17}$ Even so, Passover continued to be a family celebration; 18 the meal was eaten in the Temple courts, but probably still in family groups. ${ }^{19}$ The change in emphasis from the original event, which focused on individual families in their homes, to its commemoration as a public celebration for which the whole nation came together, may have been significant. After the covenant at Sinai, Israel was no longer to regard itself as an unconnected gathering of families and clans but as one people. The gathering of the people to celebrate the Passover symbolised the fact that they were now one family - the family of God. ${ }^{20}$

The form of the Passover Seder evolved over a long period of time. The basic elements of the meal described in Exodus 12 are the Passover lamb (pesach), bitter herbs (maror) and unleavened bread (matzah).21 Over the years several others have been added. What began as a simple meal, eaten in haste, has developed into a sophisticated ritual in which every detail is significant. Two important changes came with the destruction of the Temple in $70 \mathrm{CE}$. Up to then,

16 The Passover is believed to reflect pastoral customs going back to Israel's nomadic or semi-nomadic past, and was originally celebrated by family groups in their homes. Unleavened Bread is an agricultural festival thought to have been taken over by Israel after the settlement in Canaan. The earliest calendars mention Unleavened Bread without Passover (Ex. 23:15; 34:18) and this has led to the view that they were combined much later, probably in connection with the Deuteronomic reforms (which also made Passover a pilgrim feast); see, e.g., R. de Vaux, Ancient Israel, Its life and Institutions (London: Darton, Longman \& Todd, 1965), 484-93; Hayyim Schauss, The Jewish Festivals (London: Jewish Chronicle Publications, 1986), 38-43. It can be argued, however, that the link goes back to before the settlement; see e.g., J.G. McConville, Law and Theology in Deuteronomy, (JSOTS 33; Sheffield: JSOT, 1984), 102-10.

172 Ch. 30:17 indicates that it was customary for worshippers to kill their own lambs unless they were unclean, when the Levites might do it for them. During Josiah's Passover, however, the Levites killed all the lambs (2 Ch. 35:6); and his also seems to have been the practice after the exile (Ezr. 6:20). By the first century $\mathrm{CE}$ it was again the custom for worshippers to kill their own lambs.

${ }^{18} \mathrm{McC}$ Conville, Law and Theology, 109.

${ }^{19}$ Dt. 16:6; 2 Ch. 35:5, 12.

20 See P.C. Craigie, Deuteronomy (NICOT; London: Hodder and Stoughton, 1976), 242.

${ }^{21}$ See also Mishnah Pesachim 10:5. 
apart from a brief interlude during the exile, the lamb was central to the Passover celebration. The loss of the Temple meant that the lambs could no longer be sacrificed and so could no longer form part of the meal. It also meant that there was no central venue for the feast, and as a result the celebration became even more focused on the family meal - and it continues to be at the centre of Passover celebrations today.

Most of the information about the way Passover was celebrated in the Temple period comes from the Mishnah. This dates from the postTemple era and includes customs introduced in that period; it also reflects much earlier traditions, ${ }^{22}$ though it is not always easy to tell which is which. A chief goal of the Mishnah appears to be to demonstrate continuity between the celebration of the festival before and after the destruction of the Temple, and it includes a re-evaluation of the relative importance of the elements - in particular the centrality of the paschal lamb, which was not available after Temple sacrifices came to an end.23 As a result it is sometimes unclear which earlier practices are accurately recorded, and which are linked with a time when the Temple was still standing in order to justify later practices. This has led to disagreement as to exactly what took place during Temple times.

Nevertheless, though we cannot be sure of all the details, and while the origin of some of the customs described in the Mishnah remains uncertain, there is enough information to enable us to piece together a picture of what may have taken place during the Passover celebration at the time of Christ.

\section{The Passover Seder in the First Century CE}

The special preparations for the Passover began on the evening of 13th Nisan, ${ }^{24}$ with the removal from the home of anything containing

\footnotetext{
22 Though not put into its final form until the third century CE, the Mishnah contains material collected over a period of about 200 years, and is thought to preserve oral traditions going back to the time of Ezra.

23 The Mishnah and the supplementary collection of rabbinic teaching written shortly after it, the Tosefta, preserve the meaning of Passover without the sacrifice of a lamb. A significant change was the shift in emphasis from pesach to matzah. For further discussion see Baruch M. Bokser, The Origins of the Seder, The Passover Rite and Early Rabbinic Judaism (Berkley, CA: University of California, 1984).

${ }^{24}$ Although there is evidence of days being reckoned from sunrise to sunrise (e.g. Mt. 28:1), in general the day was reckoned from sunset to sunset. Thus the 14th Nisan began at sunset on the 13 th.
} 
leaven (chametz). In ancient times, the leaven that caused bread to rise was prepared by leaving dough lightened by grape and other juices in a warm place to ferment. Because this process took several days, and because it was seen as something of a mystery, old leaven was preserved and added to successive batches of dough. The leaven thus provided a link with the past; and the absence of leaven symbolised a break from the past and the desire for a new beginning. ${ }^{25}$ This was particularly appropriate in the context of the Passover celebrations. ${ }^{26}$

Between two and three o'clock the following afternoon, the slaughter of the paschal lambs commenced in the Temple. ${ }^{27}$ The Passover meal was eaten that night after the first stars came out (as the 15th Nisan began). In earlier days the meal was eaten in the Temple precincts; by this time, though, the number of pilgrims was so large that the area had been widened to take in the whole of Jerusalem. ${ }^{28}$ The Temple remained important, but the family-based Passover evening celebration, which took place in homes or in rooms rented for the occasion had also grown in significance. One feature of the meal was that the guests ate most of it reclining. ${ }^{29}$ This was associated with freedom, and may go back to the Persian period, where the rich reclined on divans to eat whilst slaves waited on them.

The Passover meal in the first century CE probably included the following elements.

25 This symbolic interpretation does not require that leaven is bad or undesirable in itself, though in rabbinic writings it is often used as a symbol of evil and corruption; this view is also reflected in the NT (Mt. 16:6, 11-12; Mk. 8:15; Lk. $12: 1 ; 1$ Cor. 5:6-8). See C.L. Mitton, 'Leaven', ExpT 84 (1972-73), 339-43.

${ }^{26}$ The idea of a new beginning is also seen in Ex. 12:2, where the month in which Passover is celebrated is designated the first month of your year. In the OT celebration of the Passover is often associated with important new beginnings in Israel's life (e.g. Jos. 5:10-12; 2 Ch. 35:1-19; Ezr. 6:19-21).

27 Some sources give the time as 3 p.m. - though the precise time is not clear. On 14th Nisan the offering of the regular evening sacrifice took place an hour early; this would allow the offering of the Passover lambs to begin between 2 p.m. and 3 p.m. The practice of sacrificing the Passover lambs in the afternoon of 14th Nisan rather than at twilight appears to have begun in the second century BCE. The Hebrew expression in Ex. 12:6 means literally, 'between the evenings'. This was first interpreted as the period between sunset and nightfall; later the starting point was reckoned from when the sun began its decline - i.e. from mid-afternoon onwards. See Edersheim, Temple, 211-12.

28 Josephus notes that a census held in the middle of the first century CE recorded 255,600 paschal victims, corresponding to 2,700,000 participants in the feast (The Jewish War, vi.9, 3 [Penguin Classics; Middlesex: Penguin, 1959], 359).

${ }^{29}$ Mishnah Pesachim 10:1; see also Mk. 14:18; Jn. 13:22, 28. 


\section{Blessing the Meal (Kaddesh)}

The Passover meal began with the father or the head of the company taking a cup of wine and announcing the traditional blessing, the Kiddush. This blessing was recited on Sabbaths and on other holy days and included the blessing of the wine, and the blessing of the day. ${ }^{30}$ The Mishnah prescribes that every participant should have four cups of wine during the meal, though the wine might be mixed with water to avoid drunkenness. ${ }^{31}$ Traditionally, these four cups correspond to the four promises contained in Exodus 6:6-7:

Therefore, say to the Israelites: 'I am the LORD, and I will bring you out from under the yoke of the Egyptians. I will free you from being slaves to them, and I will redeem you with an outstretched arm and with mighty acts of judgement. I will take you as my own people, and I will be your God. Then you will know that I am the LORD your God, who brought you out from under the yoke of the Egyptians'.

Luke mentions two cups at the Last Supper $(22: 17,20)$, though that does not mean there were no others. The first, the Cup of Sanctification, would have been part of Kaddesh. It was usual at Passover was for each celebrant to have his own cup, though sometimes a common cup might be used and this appears to have been the case at the Last Supper. After the blessing Jesus would have sipped from the cup and passed it to his disciples.

\section{Ritual Washing (Urchatz)}

Following the Kiddush, it was the usual practice for participants in the meal to wash their hands before touching the food. Jesus went further when he rose from the table and proceeded to wash his disciples' feet (Jn. 13:1-16).

Ritual washing was an important preliminary to eating; through it the participants prepared themselves for the meal. By doing what he did at this point in the service, Jesus pointed to the fact that true cleansing, and the only means by which his followers could be properly prepared to enjoy all that the Passover signifies, was through him. Washing the feet of the guests at the meal was an example of

30 Mishnah Pesachim 10:2. The first mention of wine in connection with the Passover meal is in the Book of Jubilees, which dates from the second century $B C E$, though it may have been included in Passover celebrations before that time.

31 Mishnah Pesachim 10:1. Some argue that the custom of drinking four cups developed later, and that during the first century only two cups were drunk - one before and one after the meal; see, e.g., Abraham P. Bloch, The Biblical and Historical Background of the Jewish Holy Days (New York: KTAV Publishing House, 1978), 148-52. 
humble service, which Jesus expected his disciples to follow (Jn. 13:12-15), and stood in sharp contrast to the disciples' pre-occupation with which of them was the greatest (Lk. 22:24).

Jesus' actions were also deeply symbolic. He took off his outer garments and wrapped a towel around his waist. This was the garb of a slave; 32 and here we see Jesus setting aside his dignity; setting aside the honour and deference that is due to him, and putting on the clothes and doing the work of a slave! Jesus knew the power and authority that was his by right (Jn. 13:3) - but he was willing to empty himself of the glory to which he was entitled, and become a servant. Paul makes the same point in Philippians 2:6-11, where he goes on to point out that following his humiliation, Jesus was exalted to the place of power and authority. Jesus had come from God and was returning to God, but in order to accomplish the purpose for which he came, and to enter into the glory prepared for him at his return, his path led through the trough of sacrifice, suffering and death. In the context of the Passover meal, it is significant that in order to redeem the world from slavery, Jesus must first offer himself as a servant.

\section{Dipping of Herbs (Karpas)}

After washing their hands the participants dipped green herbs or vegetables (karpas) into bowls of salt water. Salt water may symbolise the tears of the Israelites because of their misery in Egypt; in later days it may also have represented the tears shed over the destruction of the Temple and the loss of the land. Dipping the karpas also recalls dipping hyssop in the blood of the lamb, and smearing it on the doorposts of the houses on the first Passover night (Ex. 12:22). As well as recalling the events of the first Passover, this custom may have been introduced to provide participants with something to eat whilst they waited for the main meal during the often extended re-telling of the Exodus story. 33

32 See, e.g., C.K. Barrett, The Gospel According to St John (London: SPCK, 1955), 366. The word translated 'towel' is the Greek lention; Barrett notes that this translates the Latin linteum - which is worn by a slave in Suetonius, Caligula, 26.

33 Tabory suggests that in the early form of the celebration, the meal was eaten before the significance of the elements was explained; later this order was reversed, and during the delay participants dipped lettuce, which was already on the table, into charoseth (a mixture of wine, nuts and fruit), which was also on the table. See J. Tabory, 'Towards a History of the Passover Meal' in Bradshaw, P.F., Hoffman, L.A. (eds), Passover and Easter (Two Liturgical Traditions, 5; Notre Dame, Indiana: University of Notre Dame, 1999), 64-70; 'The Passover Eve Ceremony - an historical note', Immanuel 12 (1986), 40. However, one of the 
The Mishnah prescribes the use of lettuce (chazoret) at this point. ${ }^{34}$ This was also one of the vegetables that could be used as bitter herbs; ${ }^{35}$ at a later date it appears to have been replaced in the first dipping with another herb (parsley or celery) maybe to distinguish it from the dipping of the bitter herbs later in the meal.

According to John, Jesus dipped a morsel of food and offered it to Judas Iscariot (13:26-30). The Greek word which the RSV translates 'morsel' occurs only in this passage. It refers to a small piece of food, often bread or meat, but here, in the context of the Passover meal, it is probably best understood as a reference to the lettuce. ${ }^{36}$ The fact that this was also on the table to be eaten later as maror would further highlight the bitterness of betrayal.

\section{Uncovering the Unleavened Bread}

After dipping the lettuce, three sheets of unleavened bread were uncovered. This symbolised the unity of God's people. ${ }^{37}$ In the account of the first Passover unleavened bread was eaten because the journey was made in haste and there was no time to wait for the dough to rise. Its description as the bread of affliction (Dt. 16:3) also links it with Israel's former life of hardship. This may be symbolic; or it may be that unleavened bread was the staple diet of homes where forced labour meant that food had to be prepared and eaten quickly.

Nowadays, the host breaks the middle sheet in two; half of the broken matzah remains on the table while the other is wrapped in a cloth and hidden. After the meal this is recovered and eaten as the

child's questions relates to dipping twice, and since these almost certainly go back to Temple period, so too must the additional dipping. Tosefta 10:5 mentions salt water, though it refers to dipping innards rather than lettuce. Stallings suggests that this first course comprised roasted innards served on a bed of lettuce, and garnished with parsley and other green herbs (Rediscovering Passover, 190).

34 Mishnah Pesachim 10:3; see Stallings, Rediscovering Passover, 190; Edersheim, Temple, 237; Schauss, Jewish Festivals, 54.

${ }^{35}$ Mishnah Pesachim 2:6.

36 The Greek $\psi \omega \mu$ itov is sometimes taken to refer to a piece of unleavened bread and this is reflected in the NIV translation of this passage; see also, D.H. Stern, Jewish New Testament (Maryland: Jewish New Testament Publications, 1989); Edersheim, Temple, 246-47. It is possible to take it as a more general reference to a piece of food and the more natural understanding in this case is that it refers to the dipped herbs; see, e.g., Stallings, Rediscovering Passover, 191, 300; Barrett, John, 373.

37 The three sheets correspond either to the three divisions of the people, Priests, Levites and the nation as a whole, or to the three patriarchs, Abraham, Isaac and Jaco.b. 
afikoman - a kind of after-supper dessert. ${ }^{38}$ Hiding and eating the afikoman is a later development in the Passover tradition. So, too, is the much greater emphasis on unleavened bread, which, after the destruction of the Temple, replaced the paschal lamb as the central element of the meal. In Jesus' day, however, with the Temple still standing and sacrifices still being offered, the lamb was still central. At this stage in the proceedings the roast lamb would have been brought to the table and served with the unleavened bread and bitter herbs. At this point, too, the second cup was poured.

\section{Retelling the Story of Salvation (Maggid)}

An important aspect of Passover was its role in teaching. Prompted by questions relating to the special nature of the food, the leader explained the significance of the elements of the meal and gave a detailed account of what God had done for his people. The Mishnah lists three questions, maybe corresponding to the three references in the Bible to children asking about the Passover (i.e. Ex. 12:26; 13:14; Dt. 6:20). ${ }^{39}$

Why is this night different from all other nights?

1. On all other nights we dip once, but on this night we dip twice?

2. On all other nights we eat leavened and unleavened bread, but on this night only unleavened bread?

3. On all other nights we eat meat roasted, stewed or boiled, on this night only roasted?

${ }^{38}$ Mishnah Pesachim 10:8 includes the instruction: 'after the Passover offering do not end with afikoman'. Bokser interprets afikoman here as 'revelry' (Origins of the Seder, 31, 65) and maintains that the intention of the Mishnah is to proscribe the after dinner carousing that frequently followed banquets. A later view, reflected in the wording of the Babylonian Talmud (Pesachim 119b-120a), understands the afikoman to be a piece of unleavened bread that was served as a dessert. The purpose of forbidding afikoman would be to ensure that the Passover lamb was the last thing to be eaten.

${ }^{39}$ Mishnah Pesachim 10:4. The Babylonian Talmud (c. 500 CE) includes a fourth question: On all other nights we eat all kinds of herbs, on this night bitter herbs (Pesachim 116a), though this was almost certainly added after $70 \mathrm{CE}$ (see, e.g., Bloch, Jewish Holy Days, 131, 147; Bokser, Origins of the Seder, 29-30) maybe in response to Rabbi Gamaliel's injunction to make specific mention of three things at the meal: pesach, matzah and maror (Mishnah Pesachim 10:5). The author of this statement is probably Rabbi Gamaliel II - grandson of Paul's teacher (Acts 22:3; see also 5:34); it is probably intended to stress the continued significance of the Passover lamb, even though the sacrifice was no longer being offered. However, both Edersheim (Temple, 240) and Stallings (Rediscovering Passover, 195) include all four questions in their reconstruction of the pre-70 CE Passover Seder. 
The first question relates to the custom of dipping herbs twice: the karpas early in the Seder and, later, the maror in the charoseth. It was not unusual to dip herbs during the course of eating a meal and so it is the first dipping, before the meal, which called for an explanation. That would also explain why this question was placed first. The second question was prompted by the presence of unleavened bread only on the table. Since the bread was uncovered before the lamb was brought in this would naturally precede the question about the meat. Exodus 12:9 gives instructions that the lamb must be eaten roasted. This may have been because the speed of flight on the first Passover night made this the most suitable means of cooking. Roasting was quick; and it also allowed the blood, which Israelites were forbidden to eat, to drain from the lamb and be burned in the fire. It was also appropriate for a nomadic feast, since it required a minimum of cooking implements.

The liturgy that later came to accompany the meal (the Haggadah) was not fully developed by the first century $\mathrm{CE}$, and the Mishnah refers only to instructing the child according to his level of knowledge and understanding. However, though there may not have been a fixed response, there was a broad formula which focused on an exposition of Deuteronomy 26:5-10.40 In the course of this the leader gave a detailed account of Israel's history from the call of Abraham up to the events of the Exodus. Deuteronomy 26:5-8 opens with the words, my father was a wandering Aramean - referring to Jacob. In the Midrash on this passage, which forms part of the Passover Haggadah, it is translated instead, 'an Aramean sought my father's death' ${ }^{41}$ In this case the Aramean is Laban, whose hostility to Jacob was regarded as even greater and potentially more devastating for the nation than the actions of Pharaoh. This interpretation may have arisen out of the historical situation in the second and third centuries BCE. Pharaoh, who represented the (Egyptian) Ptolemies, is presented more favourably than Laban, who represented the (Syrian) Seleucids. The statement may have been included, originally, as a favourable gesture to the Ptolemies who first ruled Palestine. In later years, after Seleucid rule, the statement would serve as a reminder of the hardship and suffering then endured - especially during the reign of the hated Seleucid king, Antiochus Epiphanes.

40 Mishnah Pesachim 10:4.

${ }^{41}$ Craigie suggests the alternative, and probably more likely, translation 'an ailing Aramean was my father' (Deuteronomy, 321). 
After the Maggid, the first part of the Hallel (Pss. 113-114) may have been sung; ${ }^{42}$ then the second cup, known as the Cup of Freedom was drunk. ${ }^{43}$ Following this the participants washed their hands (rachtzah) as a preliminary to eating.

\section{Blessing and Breaking the Unleavened Bread}

To begin the meal proper, the host blessed the unleavened bread, broke it and shared it with those sitting around the table. At this point Jesus, too, broke the bread and passed it to his disciples - but with words that gave to the broken bread a wholly new significance: And he took bread, gave thanks and broke it, and gave it to them, saying, 'This is my body given for you; do this in remembrance of me' (Lk. 22:19). There seems little doubt that Jesus here is identifying himself with the Passover sacrifice, and pointing to the new and better deliverance that he will win for his people. ${ }^{44}$ During Maggid it was traditional to talk about the elements of the meal and explain their significance for the history of salvation. Jesus follows that custom (later than usual because of the special nature of his announcement) but shifts the emphasis from the events of the Exodus and institutes a new commemoration, centred on himself and his death. This raises an important question: if the Passover lamb was on the table, why did Jesus choose to draw attention to the bread rather than to the meat?

We have noted that the Mishnah, compiled in the post-Temple period, seeks to preserve the significance of Passover, without the lamb. One of the ways it does this is to emphasise the unleavened bread as a symbol of redemption. That, however, was not new. Even before the destruction of the Temple the unleavened bread and the Passover lamb had become closely linked and both were associated with redemption. ${ }^{45}$

42 The Hallel comprises Pss. 113-118. Bloch argues that dividing the singing of the Hallel into two parts was a later introduction to draw attention to the second cup. In his reconstruction of the first century Seder this cup was not present and the whole Hallel was recited after the meal (Jewish Holy Days, 133).

${ }^{43}$ This cup is also described as the Cup of Memory, the Cup of Instruction or the Cup of Deliverance.

44 John does not mention the bread and wine at the Last Supper; as we have seen, he identifies Jesus with the Passover sacrifice in another way.

45 Unleavened bread was associated with deliverance from Egypt from earliest times. Philo, in the first century BCE, describes unleavened bread as a Jewish symbol of redemption (Bloch, Jewish Holy Days, 112). Even during Temple times many Jews who celebrated the feast outside Jerusalem would have done so without a lamb (see Bloch, Jewish Holy Days, 134-36), and it is likely that unleavened bread played a central role. 
Jesus knew that the offering of the Passover lambs would soon cease. At one level this was due to the destruction of the Temple in 70 $\mathrm{CE}$; at a deeper level it was due to his own death, and the fulfilment, in him of all that the Passover sacrifice was intended to be. If he intended was to give his followers something that would serve as a lasting memorial of his sacrifice, it could not be the lamb. Because of Jesus' death the killing of a lamb would no longer be necessary; it would be strange indeed if believers were required to kill a lamb to commemorate the fact that they no longer needed to kill a lamb. So as not to detract from the once for all nature of his sacrifice, Jesus focused instead on the bread. This also had redemptive significance, and could be eaten as a continuing memorial whilst still upholding the cessation of animal sacrifices. Also, because the bread did not depend upon the Temple ritual it could become part of a wider celebration involving all believers, not only Jews.

As we have seen, the unleavened bread came to be regarded as a symbol of the unity of God's people. At the first Passover this was associated with the lamb, which formed the basis of the family meal. ${ }^{46}$ This is another example of how unleavened bread became closely linked with the lamb and took on symbolism formerly attached to it. The Synoptic Gospels do not record any specific reference to unity in connection with the bread; though this is important to Paul (1 Cor. $10: 16-17 ; 11: 18-32) .47$ The unity of believers is also an important theme in John's account of the Last Supper; 48 and this may partly underlie the reference to Jesus' bones not being broken (Jn. 19:36).

It is probable, too, that Jesus' words linking the bread with his body, particularly following the reference during the Maggid to God's provision of manna, would recall the discourse in John 6:48-58, where Jesus describes himself the true bread from heaven, and makes the startling announcement that eternal life comes through eating his flesh and drinking his blood. Thus, by drawing attention to the bread, Jesus identified himself with the manna as well as with the Passover sacrifice. By his death on the cross, Jesus would be the means by

46 During the first Passover, the bones of the lamb were not to be broken (Ex. 12:46). Taken alongside the instruction to eat in one house, this may emphasise the communal nature of the meal. Members of each household were united as they shared one lamb; he unity of the family groups was maintained by forbidding any part of the lamb to be broken off and taken out of the house to be eaten elsewhere. 47 This is also evident in passages that emphasise unity on the grounds that the Church is Christ's body (e.g. 1 Cor. 12:12-31; Eph. 4:1-16).

48 Jn. 17:20-23; see also, e.g., Jn. 13:1-17, 34-35. 
which his followers were to be redeemed from slavery and sustained on their journey to the Promised Land.

\section{Reliving the Exodus}

In the context of the Passover meal, 'do this in remembrance of me' means much more than recalling the past. Passover not only recalls the events of the Exodus but also seeks to involve each generation in that experience as a present reality. It is a re-actualisation of what God has done for his people during which participants are to think of themselves as if they were there. It was not just their ancestors; they had been slaves, and they had experienced the saving power of God. There is an example of this in Deuteronomy 5:2-4:

The LORD our God made a covenant with us at Horeb. It was not with our fathers that the LORD made this covenant, but with us, with all of us who are alive here today. The LORD spoke to you face to face out of the fire on the mountain.

The generation that God first spoke to had passed away, but God's interest was not only in them; all future generations of Israelites were to identify with those who had gone before as those who had, themselves, received God's promises and experienced his deliverance. During the Passover Seder, participants step back in time to relive the first Exodus, ${ }^{49}$ and as they do so the saving events associated with the first Exodus break through into the present day. Oppression and dark powers opposed to God's people are ever-present; but so too is the saving power of God giving his people hope for the future and enabling them to renew their journey to the Promised Land.

As the participants shared in the Last Supper they were already remembering what God had done for them, and were sharing in the experience of the first Exodus for themselves. When Jesus commanded them to eat the bread in remembrance of him, he introduced a significant new emphasis; nevertheless, we may suppose that the same idea of re-actualisation, which formed the basis of the Passover Seder, is intended. In the future when the disciples, and the generations of Christians who were to follow them, shared this meal they would not merely be looking back on a past event. In the Lord's Supper participants sit at the table with Christ; they are drawn into fellowship with him; and the saving events which Jesus announced -

${ }^{49}$ See BT Pesachim 116b. 
the giving of his body and the shedding of his blood - break through into the present to be appropriated afresh by his followers. ${ }^{50}$

At this point in the Seder, much to the relief of the guests, it was time to eat the meal: roast lamb served with charoseth and bitter herbs. In Jesus' day this probably included dipping the maror in charoseth (the second dipping referred to in the child's questions); and maybe wrapping some of the lamb and bitter herbs in unleavened bread, to make the Hillel sandwich.51 Whilst eating, between the second and third cups, participants were free to refill their cups and to drink as much wine with the meal as they wished. ${ }^{52}$ In Temple times the last thing eaten at the Passover meal was a piece of lamb. When sacrifices were no longer offered and roast lamb disappeared from the Passover table, this was replaced by the afikoman - the piece of unleavened bread broken from the middle sheet of unleavened bread.53 Some suggest that it was this afikoman that Jesus broke and gave to his disciples. ${ }^{54}$ This is attractive from the point of view of Christian symbolism. The three sheets of unleavened bread are then taken to represent the Trinity: Father, Son and Holy Spirit; breaking the middle piece, wrapping one of the halves in a white cloth and putting it out of sight symbolises the death and burial of the Son, and recovering it later in the meal symbolises his resurrection. 55

50 Ralph Martin, Worship in the Early Church (London: Marshall, Morgan and Scott, 1974), 118-19.

${ }^{51}$ BT Pesachim, 115a. This was named after Rabbi Hillel (b. 30 BCE). After 70 CE the 'Hillel sandwich', consisting only of unleavened bread and bitter herbs, was eaten in memory of the Temple. In the modern day celebration horseradish sauce is often used as bitter herbs and it is customary to dip a piece of bread into the sauce and then into the charoseth. According to Edersheim, this was the morsel that Jesus offered to Judas (Temple, 242), and the bread that Jesus blessed and broke was the afikoman later in the meal.

52 Mishnah Pesachim 10:7; BT Pesachim, 117b.

53 As noted above, the afikoman came to be regarded as a piece of unleavened bread eaten as an after-supper dessert. Bokser suggests that the wording in the Babylonian Talmud which has been adapted to reflect customs introduced after the destruction of the Temple and the end of the Passover sacrifices indicates that a piece of unleavened bread (identified with the afikoman) was the last thing eaten at the meal (Origins of the Seder, 65); see also Tabory, 'History of the Passover Meal, 72-73.

${ }^{54}$ A number of Messianic Jewish orders of service recall the words of institution of the Lord's Supper at this point; see, e.g., J. Lipis, Celebrate Passover Haggadah (San Francisco: Purple Pomegranate Productions, 1993) 42-43; see also Edersheim, Temple, 242-43.

55 According to Stallings, this did not happen at the Last Supper, but it became the custom among Christian Jews who wanted to attach a Christological significance to the festival (Rediscovering Passover, 301-309); see also Lipis, Celebrate Passover, 19, 42-43. 
Nevertheless, as we have noted, hiding and recovering the afikoman belongs to a later form of the Passover Seder. ${ }^{56}$

\section{Drinking the Wine}

After the meal, the third cup was filled and grace was said. This cup was, traditionally, known as the Cup of Redemption, corresponding to God's promise: I will redeem you with an outstretched arm and with mighty acts of judgement (Ex. 6:6b). It was also known as the Cup of Blessing, ${ }^{57}$ because, as with the first cup, a special blessing preceded it. ${ }^{58}$ It is widely believed that it was this cup, after supper, which Jesus took and said: 'This cup is the new covenant in my blood, which is poured out for you' (Lk. 22:20). At the first Passover, the death of the lamb and the smearing of its blood opened the way for God's redemption of the Israelites from Egypt, and the covenant at Sinai, which established their identity as God's people. 59 In the same way, the death of Jesus, which this cup foreshadows, opens the way for the redemption of the whole world from slavery to sin and the possibility of a new covenant relationship with God.

When the third cup had been drunk, the fourth cup was filled. Then the second part of the Hallel (Pss. 115-118) was sung; this is probably the hymn mentioned in Matthew 26:30. Next, it was customary to drink the fourth cup. However, as he took the third cup Jesus said: ' $I$ will not drink again of the fruit of the vine until that day when I drink it anew in the kingdom of God' (Mk. 14:25).60 This suggests that

56 Edersheim acknowledges that breaking and eating the afikoman was introduced after the cessation of the Passover sacrifice, but argues that Jesus anticipated the later practice. By making the bread rather than the lamb the last thing to be eaten, he pointed to the fact that in view of his immanent death, as a better Lamb offering a better freedom, the Passover lamb had no further meaning (Temple, 242-43). However, such a major change in the current form of the meal is bound to have led to some comment from the Gospel writers. It would also require a change in the usual order, which places thanksgiving after the eating of the afikoman. The only point at which grace precedes the breaking of bread is at the beginning of the meal.

571 Cor. 10:16.

58 This title was also given to the final cup of other festive meals.

59 In later celebrations, sharing in the Passover meal identified the participants as members of the covenant community; anyone who did not take part without good cause was to be cut off from his people (Nu. 9:13).

60 See also Mt. 26:29. In Luke's account, these words are linked with the first cup, and could mean simply that this will be the last Passover meal that Jesus will share with his disciples before his death, resurrection and ascension; however Luke may have re-arranged the order of events. If, as Matthew and Mark appear to suggest, the words were spoken just before drinking the third cup, they are more likely to relate specifically to his intention not to drink the fourth cup of wine. 
having shared the third cup Jesus intended to abstain from the fourth. 61

The fourth cup was associated with God's promise: I will take you as my own people, and I will be your God (Ex. 6:7). It is called the 'Cup of Praise', and the accompanying liturgy looks forward to God's victory over his enemies and the final vindication and future blessing of his people. 62 Jesus knew that that time was not yet; before it could come he had another cup which he must drink first: the cup of suffering and death (Mt. 26:38-39 see also Mk. 14:35-36; Lk. $22: 42) .63$ Jesus acknowledges that the day of victory and the consummation of God's rule, symbolised by the fourth cup, will come. One day the kingdom of God which, in the person of Jesus, has already broken into the kingdom of this world, will be fully established, and he will sit down at the Messianic banquet which inaugurates the new age. 64 Then, with his work done and his victory complete he will drink this cup with his disciples. For now, though, with the cross still before him, he will abstain. This has an important implication for the celebration of the Lord's Supper. It not only looks back, but also points forward to the final consummation of God's kingdom; the bread and wine is shared in remembrance of Christ's sacrifice, but also in anticipation of his final victory and of the banquet prepared when he returns. This sense of anticipation is also evident in Paul's words: For whenever you eat this bread and drink this cup you proclaim the Lord's death until he comes (1 Cor. 11:26).

\footnotetext{
61 See, e.g., W.L. Lane, The Gospel of Mark (New London Commentary; London: Marshall Morgan \& Scott, 1974), 508-509; Carson, 'Matthew', 539.

62 The destruction of the Temple in $70 \mathrm{CE}$ fuelled hope that the city and the Temple would one day be restored, free from foreign domination (Mishnah Pesachim, 10:5; see Schauss, Jewish Festivals, 56). In later days further generations of dispossessed Jews encouraged one another with the Passover benediction: next year in Jerusalem! Future hope is also symbolised by the postbiblical Cup of Elijah. Each of the participants pour a little wine from the fourth cup into the Cup of Elijah to express the hope that through their efforts final redemption would draw closer; at this point the door is opened to invite Elijah to return.

63 There is no mention of a fourth cup after the singing of the Hallel (Mt. 26:30; Mk. 14:26). This does not necessarily mean that the disciples did not drink the fourth cup (as we have noted, there is no mention of the second cup either), though it may well be that they followed Jesus example and also abstained.

64 The Messianic Banquet is indicated in passages such as Is. 25:6-9; Mt. 8:11; Lk. 14:15; see also, e.g., Mt. 22:2; 25:10; Rev. 19:9.
} 


\section{Conclusion}

In the foregoing discussion we have concluded that the Last Supper (whether or not celebrated a day early) had the character of a Passover meal, and thus would have broadly followed the form of the celebration at that time. Though it is not always easy to separate later Passover customs from those that belong to the second Temple period, we have noted several elements that are likely to have been included, and have indicated, too, their links with the events of the Last Supper.

The main theological emphasis of Passover then, as now, is the redemption of God's people from slavery in Egypt into a new life of freedom; a redemption that is not only remembered, but appropriated afresh by all who celebrate the feast, from generation to generation. That new life includes a relationship with God as his people, and Passover, too, emphasises the unity and the common identity of those who share in it. It also looks towards their final vindication. These things are evident, too, at the Last Supper, and in the instructions for the celebration of the Lord's Supper. At that meal Jesus identified himself with the traditional Passover symbols of redemption: the lamb and unleavened bread. His sacrifice is the basis for the establishment of a new covenant community, and the unity and fellowship of the participants is a significant part of the ongoing celebration of the Lord's Supper. As with the central elements of the Passover meal, sharing in the bread and wine is also a means by which successive generations of believers both recall the saving event (Jesus' death) and participate afresh in the redemption it has made possible. The celebration looks forward, too, to the consummation of God's kingdom and with it the final vindication of his people.

At the Last Supper Jesus instituted a new celebratory meal centred on himself and his approaching death. That he did so within the context of a Passover meal, focusing on traditional Passover elements, indicates continuity between the old and the new. Those present at the Last Supper would have understood Jesus' words and actions within their Passover setting. If we are to fully appreciate their significance, we need to view them within the same context. 